\title{
有明海奥部西岸域における貧酸素水塊発生時の 鉛直拡散係数及び酸素消費速度について VERTICAL DIFFUSION COEFFICIENT AND OXYGEN CONSUMPTION RATE UNDER THE OCCURRENCE OF HYPOXIC WATER IN THE INTERIOR WESTERN PARTS OF THE ARIAKE SEA
}

\author{
郡山益実 $^{1} \cdot$ 瀬口昌洋 $^{2} \cdot$ 石谷哲寛 $^{3} \cdot$ 加藤 $^{\text {治 }}{ }^{2}$ \\ Masumi KORIYAMA, Masahiro SEGUCHI, Tetuhiro ISHITANI and Osamu KATO \\ 1 正会員 農博 佐賀大学助手 農学部生物環境科学科（干840-8502 佐賀市本庄町 1 番地） \\ 2 正会員 農博 佐賀大学教授 農学部生物環境科学科（广840-8502 佐賀市本庄町 1 番地） \\ 3 農修 鹿児島大学大学院 連合農学研究科（干840-8502 佐賀市本庄町 1 番地）
}

\begin{abstract}
From the data measured in the interior western parts of the Ariake Sea in summer of 2006, vertical diffusion coefficient profiles in the water column under the formation of density stratification were clarified. Oxygen consumption was mainly caused by high consumption rate in the bottom water below the pycnocline, while the contribution of the bottom sediment to the oxygen consumption was small. The seasonal variations of vertical diffusion coefficient and oxygen consumption rate in the study area were analyzed by the two-layer box model. As a result, vertical diffusion coefficient tended to increase in summer-autumn and to decrease in winter-spring, and its seasonal variations were closely related to that of density stratification parameter. On the other hand, oxygen consumption rate tended to be positive $\left(\mathrm{O}_{2}\right.$ consumption) in spring-summer and to be negative $\left(\mathrm{O}_{2}\right.$ production $)$ in autumn-winter.
\end{abstract}

Key words : hypoxic water, vertical diffusion coefficient, oxygen consumption rate, box model, Ariake Sea

\section{1. まえがき}

近年, 有明海ではノリや二枚貝等の水産業を取り巻く 環境の悪化が深刻化しており, その要因の 1 つとして貧 酸素水塊の発生が指摘されている.

夏季に貧酸素水塊が発生する要因として, 底質及び 底層における酸素消費の増大と密度成層の形成による 酸素供給の減少が挙げられ, これまでに底質及び底層 における酸素消費速度や上層から底層への酸素供給 を左右する鉛直拡散係数に関する研究が行われてきた 1),2),3),4). 例えば, 徳永ら ${ }^{3)}$ は, 室内実験により有明海西 部海域で懸濁物質 $(\mathrm{SS})$ による酸素消費速度が底泥表 面からのそれの約7倍にも達し, SS が貧酸素水塊の形 成に重大な影響を及ぼすことを報告している。一方， Takeoka ${ }^{4)}$ は, 燧灘での海水温の観測データから鉛直 混合のみを考慮した3層のボックスモデルを用いて各層
間の鈶直拡散係数を算出し, 底層の貧酸素化が密度 躍層付近の鉛直拡散係数により大きく影響されることを 考察している. しかし, 近年, 貧酸素水塊が頻発してい る有明海奥部西岸域を対象に鉛直拡散係数の定量的 評価をした報告例は少なく, 特に現場海域で実測した 鉛直流成分から直接に鉛直拡散係数を算定した例は 見当らない.

本研究では, 有明海奥部西岸域における現地観測 データに基づいて, 密度成層と底層の貧酸素化や水質 の関連性について考察すると同時に, 実測された鉛直 流成分を基に密度成層期における鉛直拡散係数の算 定を行い, その鉛直分布性について検討した。

次いで, 同海域で採取した海水や底泥の酸素消費 実験により求めた密度躍層下における底層水及び底泥 の酸素消費速度について検討した.さらに, 1972〜 2000 年の浅海定線調査データから, 鉛直混合以外に 
水平方向の移流効果をも考慮した 2 層ボックスモデルを 用いて奥部西岸域における鉛直拡散係数及び酸素消 費速度の解析を行い, それらの季節変動の平年像につ いて明らかにした。

\section{2. 現地観測及び酸素消費実験の概要}

現地観測は, 図-1に示されるように微細土や有機物が 広く堆積し, 夏季に貧酸素水塊が頻発している奥部西岸 域の St. 1 (含泥率: 96\%) 及び St. 2 (含泥率: 94\%) で 2006 年 8 月 24 日と 9 月 2 日の計 2 回にわたり実施された.

St.1
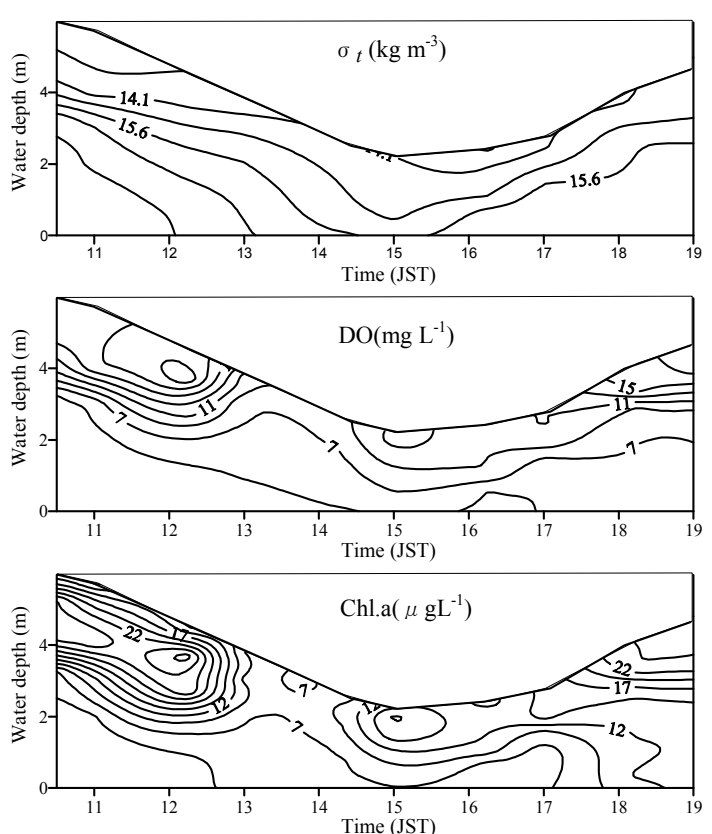

St.2
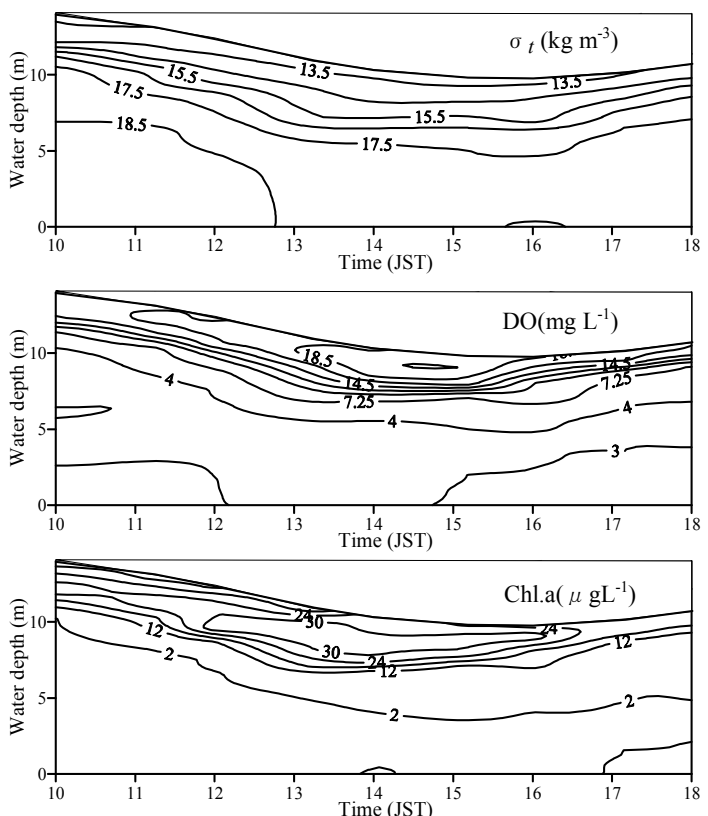

図-2 St. 1 及びSt. 2 における $\sigma_{t}$, Do 及びChl. a の鉛直分布時系列 (2006 年 8 月 24 日)

これらの観測では，両地点における水質及び流況を明 らかにするために, 多項目水質計 (AAQ1183, アレック電 子) 及び電磁流速計 (VP2400D, ケネック)を用いて, St. 1 及び St. 2 でそれぞれ梁さ $0.5 \mathrm{~m}$ 及び $1.0 \mathrm{~m}$ 毎に船上から 流速, 流向, 海水温, 塩分, DO, 濁度, クロロフィル a (Chl. a) 及び光量子の鉛直分布の経時変化を測定した.

また, St. 1 及びSt. 2 における水質分布や密度躍層下 の底層水及び底泥の酸素消費速度を明らかにするため に, 北原式採水器 (C 号, 離合社)を用いて海面下 $0.5 \mathrm{~m}$ から海底上 $0.5 \mathrm{~m}$ までの採水 (St. $1: 1 \mathrm{~m}$ 毎, St. $2: 2 \mathrm{~m}$ 毎) を 2 時間毎に 3 回ずつ行うと同時に, 観測終了時に柱 状採泥器(離合社)を用いて層厚約 $80 \mathrm{~mm}$ の未擋汼コア の採泥を行った. 採取した試料はその日のうちに実験 室に持ち帰り, 速やかに底層水及び底泥の酸素消費実 験を行った. 底層水及び底泥の酸素消費実験は, それ ぞれ沿岸環境調査マニュアル II ${ }^{5)}$ の方法と環境庁調査 方法 ${ }^{6)}$ に準拠した.

さらに, 密度成層期における海域の乱れ構造を明ら かにするために, 穏やかな快晴日であった 2006 年 9 月 2 日にSt. 1 及びSt. 2 で, それぞれ深さ $0.5 \mathrm{~m}$ 及び $1.0 \mathrm{~m}$
毎に係留した漁船から吊り下げた 3 次元精密流速計 (VECTOR, NORTEC AS) を用いて, サンプリング周波数 $64 \mathrm{~Hz}$ で 30 秒間水平及び鉛直流成分の測定を行った。

なお, 底層水の酸素消費速度の変動要因と考えられ る懸濁態有機物 (POC) に関しては, CHN コーダー (JM-10, J-Science LAB)を用いて測定した. また, 採水した海水 の無機栄養塩 $\left(\mathrm{PO}_{4}^{-}-\mathrm{P}, \mathrm{NH}_{4}{ }^{+}-\mathrm{N}, \mathrm{NO}_{3}{ }^{-}-\mathrm{N}\right.$ 及び $\left.\mathrm{NO}_{2}{ }^{-}-\mathrm{N}\right)$ 濃 度の分析は, オートアナライザー(SWAAT, BLTEC)を用い て行った。

\section{3. 結果及び考察}

\section{（1）水質の時空間的変化}

図-2 及び 3 は, St. 1 及び St. 2 の 2006 年 8 月 24 日 (大潮期) と 9 月 2 日 (小潮期) における密度 $\left(\sigma_{t}\right), \mathrm{D} 0$, Ch1. a の時空間的変化を表したものである. なお， $\sigma_{t}$ は 海水温 $(T)$ と塩分 $(S)$ 上り算出された. 図示されるよう に, 8 月 24 日におけるSt. 1 の海水の混合状態は, 全般 的に緩混合状態となっており, $\sigma_{t}$ の時空間的変化には 

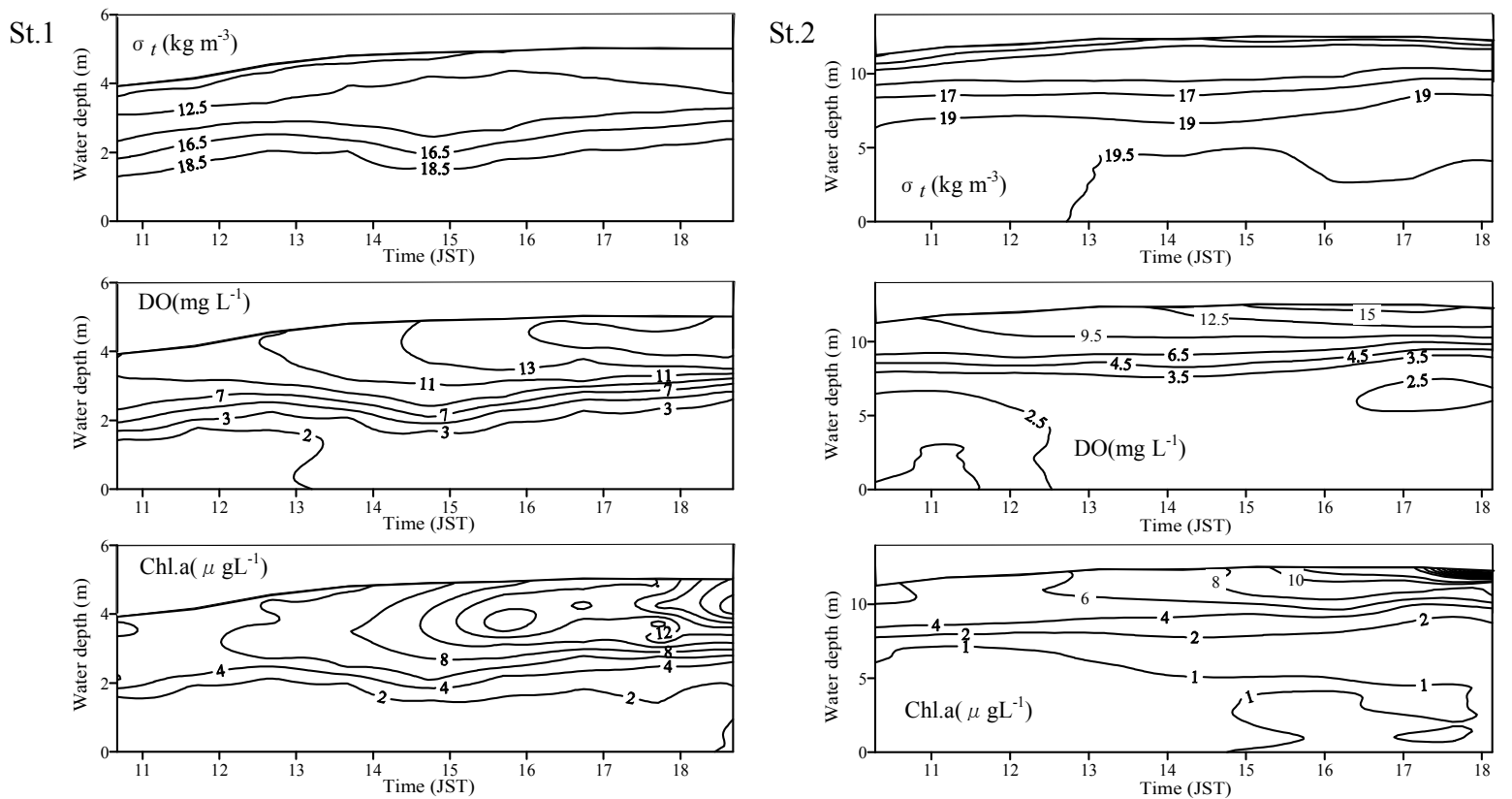

図-3 St. 1 及びSt. 2 における $\sigma_{t}$, D0 及びChl. a の鉛直分布時系列 (2006 年 9 月 2 日)

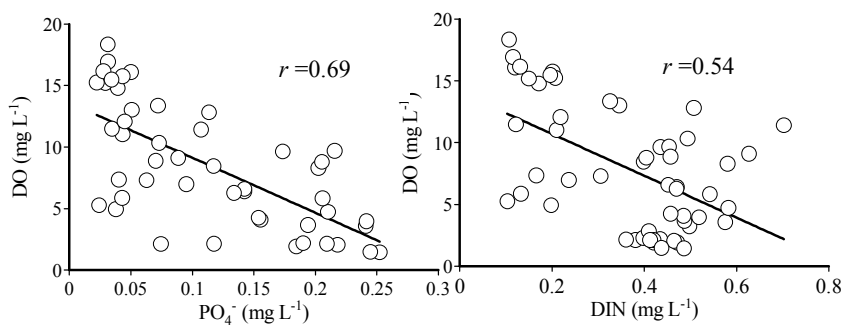

図-4 St. 1 における DO と $\mathrm{PO}_{4}{ }^{-}$及び DIN の関係

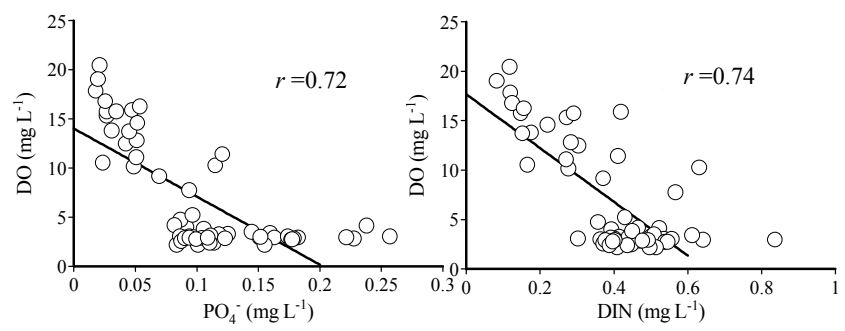

図-5 St. 2 におけるDO と $\mathrm{PO}_{4}{ }^{-}$及びDIN の関係

明確な密度成層は見られない.しかし, St. 2 において は, 明確な密度成層が見られ, D0 は表層では過飽和に, 密度躍層下の底層では 3〜 $4 \mathrm{mgL}^{-1}$ の低い状態となって いる.なお，表層部における DO 濃度の高い領域は, Ch1. a の高濃度領域と対応している. これは, 大量の植 物プランクトンが表層内に集中し, 光合成によって酸素 が生成されたために表層内の DO が増加したためと考え られる.一方, 9 月 2 日においては, St. 1 及びSt. 2 に, それぞれ海面から 2～3m 及び 4 6m の位置まで密度躍 層が存在し, 顕著な密度成層構造が形成されている. また, 密度躍層以深の D0 は $2 \sim 3 \mathrm{mgL}^{-1}$ と低い值を示し, 観測期間を通して底層の貧酸素化が見られる.

図-4 及び 5 は, 8 月 24 日と 9 月 2 日に St. 1 及び St. 2 の各水深で測定したD0 の值と採取した海水の $\mathrm{PO}_{4}^{-}$及び無 機溶存態窒素(DIN)の分析值の関係を表したものである. 図示されるように, データのバラツキが見られるものの，
両地点において $\mathrm{DO}$ と $\mathrm{PO}_{4}{ }^{-}$及び DIN の間には負の相関 性が見られ, DO 濃度の低下に伴い $\mathrm{PO}_{4}^{-}$及び DIN は増 加する傾向を示す.したがって, 底層の貧酸素化が海 底からの $\mathrm{PO}_{4}^{-}$や DIN などの溶出, さらには海域の水質 環境にどのような影響を及ぼすか, 今後詳細に検討す る必要がある。

\section{（2）密度成層期における鉛直拡散係数の鉛直分布}

図-6 及び7は, それぞれ密度成層期 (2006 年 9 月 2 日)のSt. 1 及び St. 2 における水平流速 $U$, 海水密度 $\rho\left(=\sigma_{t}+1000\right)$ 及び鉛直拡散係数 $K_{z}$ の鉛直分布の 時間的変化を表したものである. なお，ここで $K_{z}$ は，鈆 直方向の流速データから有義波高の平均周期に相当 する約 2 秒の移動平均值を差し引いた偏差を乱れ成分 とし, 次式により算出された.

$$
K_{z}=\beta \overline{w^{\prime 2}} \int_{0}^{\tau_{c}} R_{w}(\tau) d \tau
$$

ここに, $\overline{w^{2}}$ は鉛直方向の変動流速の二乗平均值, $\tau_{c}$ は自己相関係数が最初に 0 になるまでの時間 ${ }^{7)}, R_{w}$ は 鉛直方向の流速の自己相関係数, $\beta$ は Euler 自己相 関係数と Lagrange 自己相関係数を関連付ける無次元 パラメータで, 村上ら ${ }^{7)}$ になら $\beta=1$ とした.

図示されるように, 両地点で $U$ は深さと共に増加し, ある水深で最大值に達した後, 減少する. さらにUは, 密度躍層以深ではほぼ一様な分布傾向を示す.一方, $K_{z}$ は表層及び底層付近で高く, 密度踓層下端で低下 する傾向が見られる. また, 表層及び底層における $K_{z}$ は，それぞれ 3.1〜21. $9 \mathrm{~cm}^{2} \mathrm{~s}^{-1}$ 及び $11.4 \sim 60.0 \mathrm{~cm}^{2} \mathrm{~s}^{-1}$ と大きく変動しているのに対して, 密度躍層下端付近の $K_{z}$ の変動は $3.6 \sim 7.5 \mathrm{~cm}^{2} \mathrm{~s}^{-1}$ と小さい. このことから, 密 


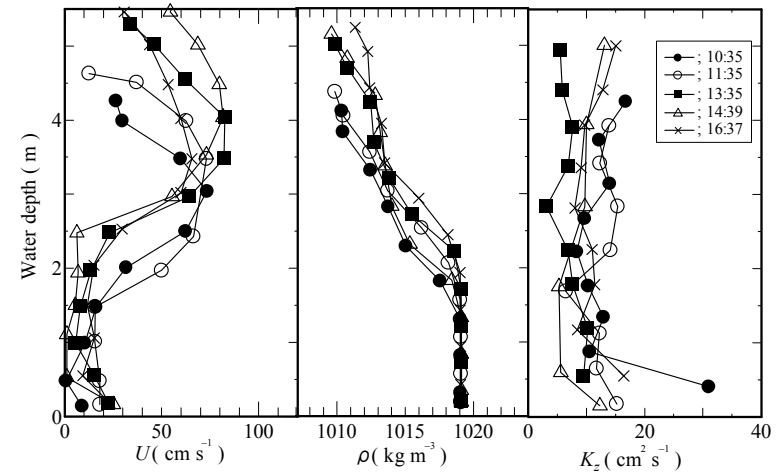

図-6 St. 1 における $U, \rho$ 及び $K_{z}$ の鉛直分布

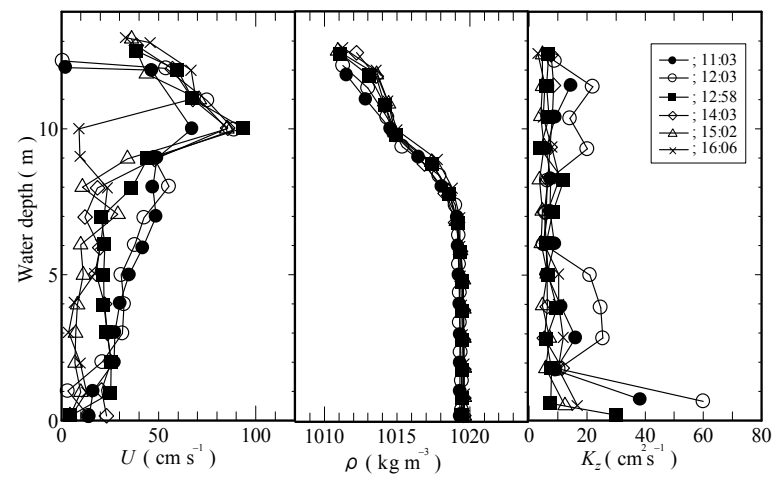

図-7 St. 2 における $U, \rho$ 及び $K_{z}$ の鉛直分布

度躍層の形成により上下層間の鉛直混合は制限される ものと考えられる. したがって, 安定した密度成層の形 成は, 密度躍層がひとつの障壁となり上層から下層へ の酸素供給を抑制していると推察される.

また, 密度成層期における $K_{z}$ は, 一般に (2) 及び (3) 式に示される Munk・Anderson の経験式 ${ }^{8)}$ により表される. したがって, 両式により, St. 1 及び St. 2 の $K_{z}$ を求める と, それぞれ 7. 3〜 38. $8 \mathrm{~cm}^{2} \mathrm{~s}^{-1}, \quad 5.2 \sim 31.6 \mathrm{~cm}^{2} \mathrm{~s}^{-1}$ となる. これらの值は, 本研究で得られた $K_{z}$ と比較的近い. な お, 式中の $\partial \rho / \partial z$ 及び $\partial U / \partial z$ は, 各測点間の $\rho$ 及び $U$ の鉛直勾配より算出した.

$$
\begin{aligned}
& K_{z}=K_{0}\left(1+a R_{i}\right)^{-b} \\
& R_{i}=-\frac{g}{\rho} \frac{\frac{\partial \rho}{\partial z}}{\left(\frac{\partial U}{\partial z}\right)^{2}}
\end{aligned}
$$

ここに, $K_{0}$ は中立状態 $\left(R_{i}=0\right)$ の場合の鉛直拡散係 数で $K_{0}=1, a=3.33, b=3 / 2, R_{i}$ はリチャードソン 数, $g$ は重力加速度, $z$ は鉛直座標である.

\section{（3）底層水及び底泥の酸素消費速度}

表-1は, 2006 年 8 月 24 日と 9 月 2 日にSt. 1 及び St. 2 で採取した底層水と底泥を用いて酸素消費実験を 行った結果を一覧したものである. 両地点における底泥 の酸素消費速度 $\left(R_{S}\right)$ は, $1.09 \sim 1.49 \mathrm{gm}^{-2} \mathrm{~d}^{-1}$ の範囲に あり, 中山ら ${ }^{9)}$ が 2002 年 7 月に有明海北西部で得た $R_{s}$
表-1 St. 1 及び St. 2 における $R_{s}, R_{w}$ 及び $R_{s w}$

\begin{tabular}{lcccc}
\hline & 調查地点 & $\begin{array}{c}R_{s} \\
\left(\mathrm{gm}^{-2} \mathrm{~d}^{-1}\right)\end{array}$ & $\begin{array}{c}R_{w} \\
\left(\mathrm{mgL}^{-1} \mathrm{~d}^{-1}\right)\end{array}$ & $\begin{array}{c}R_{s w} \\
\left(\mathrm{mgL}^{-1} \mathrm{~d}^{-1}\right)\end{array}$ \\
\hline \multirow{2}{*}{$2006 / 8 / 24$} & St.1 & 1.25 & $0.78-1.67$ & $1.41-2.30$ \\
& St.2 & 1.49 & $0.56-1.68$ & $0.91-1.89$ \\
\hline \multirow{2}{*}{$2006 / 9 / 2$} & St.1 & 1.25 & $0.00-1.73$ & $0.62-2.36$ \\
& St.2 & 1.09 & $0.00-2.16$ & $0.16-2.32$ \\
\hline
\end{tabular}

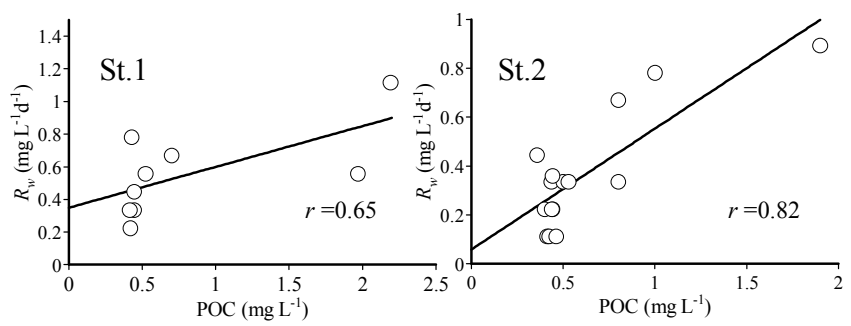

図-8 St. 1 及びSt. 2 の底層における $R_{w}$ と POC の関係

の実測值 $0.84 \sim 1.04 \mathrm{gm}^{-2} \mathrm{~d}^{-1}$ とほぼ同程度の值である.

また, St. 1 及び St. 2 における密度躍層下の底層水 の酸素消費速度 $\left(R_{w}\right)$ は, 平均でそれぞれ 1.01 $\mathrm{mgL}^{-1} \mathrm{~d}^{-1}, 1.14 \mathrm{mgL}^{-1} \mathrm{~d}^{-1}$ である. さらに, 9 月 2 日の観測結 果より密度躍層下端から海底までの深さを底層厚とする と, 底層厚はSt. 1 で $2 \mathrm{~m}$, St. 2 で $7 \mathrm{~m}$ となり, 密度躍層下 の底層水々底泥を含めた層内の酸素消費速度 $\left(R_{s w}\right)$ は, 平均でそれぞれ $1.64 \mathrm{mgL}^{-1} \mathrm{~d}^{-1}$ 及び $1.33 \mathrm{mgL}^{-1} \mathrm{~d}^{-1}$ と なる.したがって, $R_{w}$ の $R_{s w}$ に占める割合は, St. 1 で 平均 $63.2 \%$, St. 2 で平均 $79.2 \%$ であり, 密度躍層下に おける酸素消費には $R_{w}$ が大きく寄与しているものと推 察される. また, 本研究で得られた $R_{s w}$ の值は, 中山ら 9) や徳永ら ${ }^{3)}$ が見積もった海底から $5 \mathrm{~m}$ 層内の酸素消費 速度 $\left(0.19 \sim 1.31 \mathrm{mgL}^{-1} \mathrm{~d}^{-1}, 1.54 \mathrm{mgL}^{-1} \mathrm{~d}^{-1}\right)$ とほぼ同程 度の值である.

図-8 は, 8 月 24 日の St. 1 及びSt. 2 における底層水 の $R_{w}$ とPOC との関係を表したものである. 図示されるよう に, 両者の間には比較的高い正の相関が見られ, POC の増加に伴い $R_{w}$ は増大寸る.これは, $R_{w}$ が海水中の 㲘濁態有機物量に依存寸ることを示しており, 潮流や 波浪により巻き上げられて形成された高濁度層は, 底 層付近の DO の消費に大きく影響するものと考えられる.

\section{4. ボックスモデル解析}

\section{（1）使用データ}

解析に用いた $T, S$ 及び D 0 のデータは, 図-1 に示さ れるSt. A〜J で, 佐賀県有明水産研究センターが毎月 大潮時に観測したデータを水産総合研究センター西海 区水産研究所が取り緾めたものである. 各測点の $T, S$ 及び D0 のデータは, 海面下 $0 \mathrm{~m}, 5 \mathrm{~m}, 10 \mathrm{~m}, 20 \mathrm{~m}, 30 \mathrm{~m}$, $40 \mathrm{~m}$ で得られており, 本研究では, これらのデータを水 
深 $1 \mathrm{~m}$ 間隔に線形補間した. なお， $\rho$ は $T$ 及び $S$ のデー タより算出した. 気象データに関しては, 佐賀地方気象 台で得られた毎月の平均值を用いた. また, 有明海奥 部西岸域に流入する河川流量に関しては, 集水面積と 月降水量から推定した。

\section{(2) 解析方法}

本研究では, 貧酸素水塊が頻発する有明海奥部西 岸域の図-1の破線で囲まれた海域を図-9 に示される 2 層のボックスモデルで近似した.上下ボックスの境界深 さ $\left(H_{1}\right)$ は 2005 年 8 月の現地観測で得られた密度躍層 の水深 $4 \mathrm{~m}$ とした. 上下層内の塩分 $\left(S_{1}, S_{2}\right)$ 及び D0 $\left(C_{1}, C_{2}\right)$ は, 各層内に含まれる St. A E (図-1)の $S$ と D0 の值を平均して求めた. また, 東西方向のボックス外 の塩分 $\left(S_{3}, S_{4}\right)$ 及び $\mathrm{D} 0\left(C_{3}, C_{4}\right)$ と南北方向のボックス 外の塩分 $\left(S_{5}, S_{6}\right)$ 及び DO $\left(C_{5}, C_{6}\right)$ は, それぞれ St.F 〜 H(図-1) 及び St. I〜J(図-1)の $S$ とD0 の值を海面 $\sim H_{1}$ と $H_{1}$ 以深で平均して求めた. なお, 各ボックスの 諸元は表-2 に一覧される.

ここで, 各ボックスにおける塩分収支及び水収支は， それぞれ次式で表される.

Box 1

$$
\begin{gathered}
V_{1} \frac{d S_{1}}{d t}=-u_{1} A_{1} S_{13}+w A_{12} S_{12}+u_{3} B_{1} S_{15} \\
+\frac{K_{z}\left(S_{2}-S_{1}\right) A_{12}}{H_{12}} \\
u_{1} A_{1}=Q+w A_{12}+u_{3} B_{1} \\
Q=Q_{r}+Q_{p}-E
\end{gathered}
$$

Box2

$$
\begin{aligned}
V_{2} \frac{d S_{2}}{d t}=- & u_{2} A_{2} S_{24}-w A_{12} S_{12} \\
& +u_{4} B_{2} S_{26}+\frac{K_{z}\left(S_{1}-S_{2}\right) A_{12}}{H_{12}} \\
& u_{2} A_{2}=-w A_{12}+u_{4} B_{2}
\end{aligned}
$$

ここに, $V_{1}, V_{2}$ はそれぞれ上層及び下層ボックスの体積, $A_{12}, A_{1}, A_{2}, B_{1}, B_{2}$ はそれぞれ上下ボックスの水平断面 積, 上下ボックスの東西方向の鉛直断面積及び南北方 向の鉛直断面積， $u_{1}, u_{2}$ はそれぞれ東西方向の上層及 び下層の水平流速, $u_{3}, u_{4}$ はそれぞれ南北方向の上層 及び下層の水平流速, $w$ は上下ボックス間の鉛直流速, $H_{12}$ は上下ボックスの中央点間距離, $S_{i j}=$ $\left(S_{i}+S_{j}\right) / 2, Q$ は上層ボックスへの淡水流入量で, 河 川からの流入量 $\left(Q_{r}\right)$ と降雨量 $\left(Q_{p}\right)$ 及び蒸発量 $(E)$ を 考慮した正味の值であり, $E$ は次式により推定された ${ }^{10)}$.

$$
E=k\left(E_{s}-E_{a}\right) W
$$

ここに, $k$ は蒸発係数 $\left(=0.17 \mathrm{mmd}^{-1} \mathrm{hPa}^{-1} \mathrm{sm}^{-1}\right)^{10)}, E_{s}$ は 観測された海面水温から計算した飽和蒸気圧, $E_{a}$ は

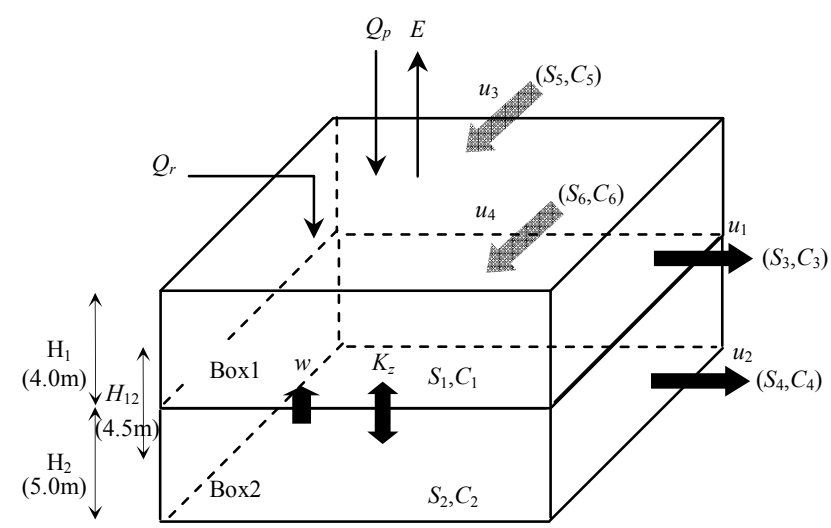

図-9 ボックスモデルの概要

表-2 各ボックスの諸元

\begin{tabular}{ccc}
\hline Volume $\left(\mathrm{km}^{3}\right)$ & $V_{1}$ & 0.426 \\
& $V_{2}$ & 0.533 \\
\hline Interface Area $\left(\mathrm{km}^{2}\right)$ & $A_{12}$ & 106.56 \\
\hdashline$-0.0-1$ & 0.029 \\
\hline Cross Section Area $\left(\mathrm{km}^{2}\right)$ & $A_{1}$ & 0.037 \\
(East-West) & $A_{2}$ & 0.058 \\
\hline Cross Section Area $\left(\mathrm{km}^{2}\right)$ & $B_{1}$ & 0.072 \\
\hline (North-South) & $B_{2}$ & \\
\hline
\end{tabular}

佐賀気象台で観測された月平均大気蒸気圧, $W$ は佐 賀気象台で観測された月平均風速である.

(4)，(5)，(7)，(8) 式から明らかなように, これらの式 中には未知数は $u_{1} \sim u_{4}, w, K_{z}$ の 6 個あるため, 解析的 に未知数を求めることは出来ない。 そこで, ここでは 1972２000 年の各月 29 個のデータについて, 最小二 乗法を適用し, 各月の未知数を決定した ${ }^{11)}$.

一方, 下層ボックスにおける DO 濃度の時間的変化を 支配する方程式は, 次式で表される.

$$
\begin{aligned}
V_{2} \frac{d C_{2}}{d t}=-u_{2} A_{2} C_{24} & -w A_{12} C_{12}+u_{4} B_{2} C_{26} \\
& +\frac{K_{z}\left(C_{1}-C_{2}\right) A_{12}}{H_{12}}-V_{2} R
\end{aligned}
$$

ここに, $C_{i j}=\left(C_{i}+C_{j}\right) / 2, R$ は生化学的な酸素消費 速度である。

\section{（3）解析結果及び考察}

図-10 は, ボックスモデルにより得られた解析対象海 域における $K_{z}$ 及び $R$ と密度成層度 $(P)^{12)}$ の月変動を 表したものである. なお， $P$ は次式で定義される.

$$
\begin{aligned}
& P=\int_{0}^{H}|\rho(z)-\bar{\rho}| g d z \\
& \bar{\rho}=\frac{1}{H} \int_{0}^{H} \rho(z) d z
\end{aligned}
$$

ここに，H は水深である.

図示されるように, $K_{z}$ は $P$ の季節変動とは逆に, 夏 季〜秋季に減少し, 冬季〜春季に増加する季節変動を 


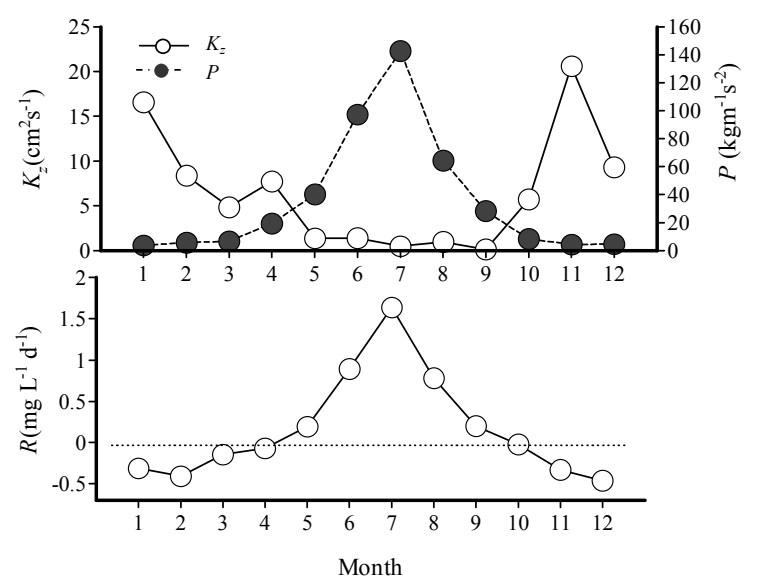

図-10 $P, K_{z}$ 及び $R$ の月変動

示す. すなわち, 夏季〜秋季においては淡水流入量の 増加や海面加熱などにより密度成層が発達するために 海水の鉛直混合が抑制される結果， $K_{z}$ は減少する. し かし, 冬季〜春季にかけては淡水流入量の減少や海面 冷却などにより密度成層が弱まり, その結果, 海水の鉛 直混合が促進されるために, $K_{z}$ は増加するものと推察 される.

一方， $R$ は春季〜夏季に正となり, 秋季〜冬季に負 となる傾向を示す. $R$ のこのような変化は, 下層での生 化学的な $\mathrm{O}_{2}$ の消費と生産の季節変動を示すものであり, 春季〜夏季における $\mathrm{O}_{2}$ の消費には, 海水温の上昇や 海水中の有機物量の増加が, また秋季〜冬季における $\mathrm{O}_{2}$ の生産には, 透明度の上昇による植物プランクトンの 光合成の活性化が大きく関与しているものと考えられる. なお, 本解析で得られた夏季の $R$ は $1.0 \sim 1.5 \mathrm{mgL}^{-1} \mathrm{~d}^{-1}$ で，3.(3)の酸素消費実験により見積もられた $R_{s w}(1.29$ $\left.\sim 1.64 \mathrm{mgL}^{-1} \mathrm{~d}^{-1}\right)$ と同程度の值である.

\section{5. まとめ}

今回の研究で得られた主な知見は, 次のように要約さ れる.

(1)St. 1 及びSt. 2 における現地観測より, $\sigma_{t}$, D0 及び Chl. a の時空間的変化が把握され, 小潮期において St. 1 及びSt. 2 では, それぞれ海面下 $2 \sim 3 \mathrm{~m}$ 及び 4 $6 \mathrm{~m}$ の位置まで密度躍層の形成が見られた. また, 海水 中の $\mathrm{PO}_{4}^{-}$及び DIN は, DO の低下と共に増大寸る傾向を 示した.

(2) St. 1 及びSt. 2 で実測された鉛直流成分から $K_{z}$ が 算定され, 密度成層期における $K_{z}$ の分布性が明らか にされた. 寸なわち, $K_{z}$ は表層及び底層で高く, 密度 躍層下端付近で低下寸る傾向を示した. したがって, 海 水の密度成層化は, 表層から下層への酸素供給能力 を抑制するものと考えられた。

(3) 酸素消費実験の結果より， $R_{w}$ の $R_{s w}$ に占める割合 は, St. 1 で平均 $63.2 \%$, St. 2 で平均 $79.2 \%$ であった. ま
た, 両地点における $R_{w}$ は POC の増加に伴い増大寸る 傾向を示した.このことより, 底層 D0 の消費には潮流や 波浪などにより巻き上げられて形成された高濁度層が 大きく影響するものと推察された.

（4）1972２000 年の浅海定線調査データを用い, 2 層 ボックスモデルより奥部西岸域における $P, K_{z}$ 及び $R$ の解析を行った. その結果, $K_{z}$ は $P$ とは逆に夏季〜 秋季に減少し, 冬季〜春季に増加する変動傾向を示し た. また, $R$ は春季〜夏季に正 $\left(0_{2}\right.$ 消費 $)$, 秋季〜冬季 に負 $\left(\mathrm{O}_{2}\right.$ 生産 $)$ となる季節変動を示した。

謝辞: 本研究を実施するに際し, 平成 17 年度科学研究 費補助金(基盤研究 (B), 代表: 瀬口昌洋)及び佐賀大 学有明海総合研究プロジェクトより, 多大なる支援を受 けた.このことを，ここに付記し，深謝申し上げます．

\section{参考文献}

1）中村由行, 西田克司, 早川典生: 閉鎖性内湾における温 度成層の形成のモデル化, 海岸工学論文集, 37, pp. 794-798, 1990.

2）星加章, 谷本照己: 大阪湾における底層環境の酸素消 費, 中国工業技術研究所報告, 44, pp. 39-44, 1995.

3）徳永貴久, 松永信博, 阿部淳, 児玉真史, 安田秀一: 有 明海西部海域における高濁度層の観測と懸濁物質によ る酸素消費の実験, 土木学会論文集, No. 782/II -70, pp. 117-129, 2005.

4) Takeoka,H., T.T.Ochi, and K.Takatani : The anoxic water mass in Hiuchi-nada Part 2. The heat and oxygen budget model. J. Oceanogr. Soc. Japan, 42, pp.12-21, 1986.

5）日本海洋学会編: 沿岸環境調査マニュアル II , 恒星社厚 生閣, 東京, pp. 296, 1990.

6）環境庁:瀬戸内海の干潟, 浅海域の浄化機能, 平成 11 年度環境庁委託業務報告書, pp. 134, 2000.

7）村上和男, 森川雅行: 超音波流速計による潮流観測と水 平・鉛直拡散係数の算定, 港湾技術研究所報告, 22 (2), pp. 175-211, 1983.

8) Munk W.H.,E.R.Anderon : Notes on a theory of the thermocline, J.Mar.Res.,7,pp.276-295,1948.

9) 中山哲嚴, 佐伯信哉, 時吉学, 木元克則: 有明海北西部 で発生する貧酸素水塊に着目した現地調査, 海岸工学 論文集, 50, pp. 976-980, 2003.

10）柳哲雄, 安部良平: 有明海奥部における塩分と DIP・DIN 収支の経年変動, 海の研究, 14(1), pp. 21-33, 2005.

11）柳哲雄，下村真由美: 有明海における鉛直循環流の経 年変動, 九州大学大学院総合理工学報告, 27 (4), pp. 367-371, 2006.

12）柳哲雄,下村真由美: 有明海における成層度の経年変 化, 海の研究, 13 (6), pp. 575-581, 2004.

(2006. 9. 30 受付) 